\section{Cetus and Chiron merge}

\section{Washington}

AFTER almost a year spent courting a corporate partner, Cetus Corporation of Emeryville, California, announced last week its intention to merge with neighbouring Chiron Corporation in a transaction valued at approximately $\$ 660$ million. The merger is contingent upon the sale of Cetus's PCR (polymerase chain reaction) business to Hoffman-La Roche Holdings for a planned $\$ 300$ million.

The combined company will keep the Chiron name, which is best known for the discovery of the hepatitis $\mathrm{C}$ virus. The new Chiron, which will have a joint worldwide workforce totalling 1,400 employees, expects eventually to cut its staff by 10 per cent to eliminate overlapping functions and allow full integration of the two companies.

The company will focus on four key areas of research: diagnostics; biopharmaceuticals, with an emphasis on cancer drugs; vaccines; and ophthalmics. Together, Chiron and Cetus have 22 products in human clinical trials.

The former rivals complement each other's strengths. Cetus not only provides Chiron with an entry into the therapeutic market through its oncology business, but also offers access to its specialized marketing and sales force both in the United States and through its European arm, EuroCetus. In addition, Chiron will be able to accelerate product development by tapping into the excess capacity of Cetus' manufacturing facility. "That's worth a lot of money to us", says Rutter. "We [Chiron] will use manufacturing as a competitive advantage now."

With a combined cash balance of $\$ 600$ million after completion of the merger, which includes the $\$ 300$ million payment by Roche for PCR, it is unlikely that the new company will have to "worry about the short-term vicissitudes of the financial markets", says Ron Cape, chairman and chief executive officer of Cetus.

Cetus was dealt a severe blow in July last year when a US Food and Drug Administration (FDA) advisory committee failed to recommend approval of its key product, interleukin-2 (Proleukin), for the treatment of metastatic kidney cancer, even though no alternative treatment was available. The same product is approved for sale in nine European countries. This caused a rapid reversal of fortune, causing a precipitous drop in share prices and triggering a management shake-up after Robert Fildes quit the top job as chief executive officer in August 1990. In the ensuing months, Cetus embarked upon a series of cost-cutting measures in an attempt to curb operating expenses and win back the confidence of Wall Street and its investors. All of this fuelled speculation that Cetus was ripe for a takeover bid.

Margaret McGeorge, an analyst with Sutro and Co., says that from Chiron's standpoint it is an "opportunistic acquisition" as the company is not paying a huge premium for Cetus.
Robert Kupor, an analyst with Kidder Peabody, was less enthusiastic. Whereas most biotechnology companies are fairly conservative and stick close to their core technology, Kupor says that Chiron has shown the greatest tendency towards "empire building". He estimates that the crossover point when the new Chiron will be making as much as the old Chiron could be as far off as 1994 or 1995 . "In other words, too far out for people to have any confidence in financial models," Kupor says.

News of the merger met with a cool response on Wall Street. Cetus's stock dipped 2.25 to 15.615 and Chiron's plunged 6 points to 54.75 on the day the news broke, amid concern among financial analysts that the merger could stifle Chiron's earnings momentum. As biotechnology companies go, Chiron has enjoyed considerable financial success and is in its fifth consecutive quarter in the black. By contrast, Cetus's losses for fiscal year 1990 totalled $\$ 61$ million.

Under the agreement, Chiron will exchange three-tenths of a share of newly issued Chiron stock for each share of Cetus stock. The ratio will be adjusted if Chiron stock tops $\$ 67$ per share or dips below $\$ 49$ over a fixed period of time. In addition, Chiron will assume $\$ 145$ million of Cetus' outstanding debt.

In addition to various regulatory clearances, the merger is subject to a majority approval by both Cetus and Chiron stockholders in meetings scheduled for early November. The two companies expect to merge by the end of the year.
Diane Gershon

\title{
Is Cetus selling the family silver?
}

\section{Washington}

It was only five months ago that.Cetus emerged victorious from a federal court hearing in San Francisco with secure basic patent rights to polymerase chain reaction (PCR) technology, after a challenge by Du Pont. Now Cetus plans to sell its PCR business lock, stock and barrel to Hoffman-La Roche for $\$ 300$ million plus royalties. PCR - a technique for rapidly amplifying DNA in vitro - has revolutionized molecular biology since its development by Cetus in 1985 and has found broad application in the detection of genetic disorders, cancer and infectious diseases, paternity testing and forensic analysis.

While some might see spinning off the PCR division to Roche as selling the family silver, the deal actually seems to make sense for both Cetus and Roche. On the one hand, Cetus has already licensed most of the practical rights to PCR technology. On the other, Roche is developing and com- mercializing in vitro human diagnostic products and services that are based on PCR technology for diseases such as AIDS, Lyme disease and tuberculosis. (And, through the Perkin-Elmer Cetus Instruments joint venture, in which Perkin-Elmer has a 51 per cent stake and Cetus owns 49 per cent, PCR technology is being used to develop instrumentation for the research and industrial markets.)

Under the new agreement, Roche will acquire ownership of PCR technology from Cetus, a transaction that includes all the technical, patent and manufacturing rights relating to PCR, although Cetus will retain the right to use PCR technology in connection with its therapeutic research. The Cetus and Perkin-Elmer joint venture will be dissolved and a new strategic alliance between Roche and Perkin-Elmer will be set up.

Ron Cape, chairman and chief executive officer of Cetus expects that the commercialization of PCR technology will be more dynamic under Roche than it could have been under Cetus' control.

"PCR is worth more to Roche than it is to us", he says, particularly as most of the profitability with PCR is expected to be in clinical diagnostics. "Roche made us an offer we literally could not refuse", Cape says, and so Cetus opted for the cash in hand rather than a steady stream of future income.

Clearly, Roche is "willing to pay a premium to have full control of that business", says Jim McCament of the Medical Technology Stock Letter. "It makes perfect sense that they would buy the technology that they already have rights to", says Margaret McGeorge, an analyst with Sutro \& Co.

With the sale of the PCR business goes Cetus' PCR division, which generated revenues of almost $\$ 21$ million in fiscal year 1990. Most of the division's 125 researchers are expected to move over to Roche's PCR facility in Alameda, California. 